\title{
라오스 원조동향
}

\section{I. 일본의 대라오스 지원}

- 일본은 2003 2004년도 주재국에 84백만 불을 지원하여 최대 공여국으로 일본 NGO 또 는 국제 $\mathrm{NGO}$, 민간기업과 연계하여 다양한 분야에서 원조를 실시하고 있다. 대라오스 주 요 지원분야는 인적자원개발(단 - 장기연수, 장학사업), 인프라구축(도로망확충, 교랑건설 등) 보건분야 등이다.

- 금년도 4 월까지의 일본의 주요 원조동향은 아 래와 같다.

\section{1. 산업인프라 분야}

- 힌업지역 교량 건설

- JICA는 13 번 도로(왓타이공항 $\rightarrow$ 외곽지역) 가 연결되는 교통난이 심한 힌업지역에 새 교
량을 건설할 계획이며, 통신교통체신건설부 와 교량 건축을 위한 조사를 위한 협정식을 갖고 $\mathrm{JICA}$ 전문가가들을 파견, 8월부터 교량 건축을 위한 조사 및 설계에 착수하여 2007 년 말 완공 예정이다.

- 캄무안주에 Community center건립 - 캄무안주 인본군 송홍마을에 일본에서 진출 한 민간기업 Oji Lao Forest Plantation에서 30 만불의 예산으로 5 개의 게스트 하우스, 휴 식공간, 미팅 및 교육실, 박물관, 양호실이 있 는 회관을 건립하였으며 박물관에는 라오와 일본 출판물들이 전시될 예정이다. 동 센터에 서는 어린이들의 미술활동, 일본어, 영어교육 이 실시될 예정이며 동 센터는 마을주민이 자 유로이 이용할 수 있도록 하고 게스트 하우스 는 일본이나 라오 정부관리들의 이용이 가능 하다. 동 회사는 이 지역에 도로건설, 전기보 
급을 하였으며 향후 마을 발전을 위한 중소기

업 운영기금을 조성하여 빈곤퇴치를 위한 마 을 경제 발전도 지원할 계획이다.

\section{2. 교육훈련 분야}

- 학교교복 지원

- 일본은행(도쿄미스비시)은 비엔티엔에 6,000 벌의 여학생 교복을 지원하며 동 지원은 국가 재활센터에 기증되어 사이타니, 박음과 상통 지역의 학생들에게 배포되고 각 복지시설 및 농촌 마을에도 지원될 예정이다. 금번 지원은 동 재활센터에서 활동하고 있는 일본재난구 호협회 주선으로 이루어질 예정이다.

\section{3. 공공행정 분야}

- 법제정비 지원

- 일본과 라오스가 법제정비 프로젝트에 대한 평가회를 개최한다. 이번 합동 최종회의는 법 무부, 대법원, 검찰 및 일본측 대표자들이 참 석하였으며 일본정부는 JICA를 통하여 주재 국 법무부와 1998년부터 법제개선 분야를 지 원하여 왔다. 동 평가회는 그간 실시한 프로 젝트의 적정성, 효과성, 효율성, 영향력, 지속 성의 5 개 카테고리에 대한 결과와 수행방법, 관련기관을 평가한다. 평가기준은 $\mathrm{OECD}$ 의 $\mathrm{DAC}$ 원칙에 의거하여 JICA가 제시한 가이드 라인에 맞추어 시행된다.

\section{4. 의료보건 분야}

- 의료물류센터 건립

- 일본은 라오스 북부 및 남부지역에 의료물류 센터 건립을 지원함. 우돔사이지역에는 81천 불, 참파삭에 78 천불을 투입하였다. 민간분 야 차원 생명보호 프로젝트 무상원조의 일환 으로 5 개월간에 걸쳐 건립되었다.동 프로젝 트는 약품과 의료장비를 알맞는 조건에서 보 관하므로써 보건의료서비스 개선, 의약품 및 의료설비의 효과적인 관리 능력 배양이 목적 이며 동 의료물류센터는 두 지역 뿐만아니라 인근지역에서도 활용이 가능하다. 일본은 라 오스 전역을 대상으로 말라리아 센터, 병원, 보건소 건립을 지원한 바 있다.

- 병원개보수 지원

- 일본은 10 개의 지역병원과 비엔티엔시내의 수도공급시스템을 지원할 계획이며 이는 10 개 지역병원의 개보수와 수도의 수도공급시 스템 개선 지원이 포함된다. 첫 번째 단계로 현재 카오레오와 치나이모지역의 수도시설을 비엔티엔 중심까지 연장 3.6 억불 예산을 투 입할 계획이며 10 개 지역병원의 의료기구 및 시설 확충을 위하여 13 억불을 지원 예정이다. 


\section{4. 기타}

- 홍수피해 농민들에게 미곡 지원

- 일본정부, 노동복지부 및 주민들이 참석한 가 운데 300 백만엔 상당의 쌀7,900톤을 기증하 였다. 2004년 시작된 KR1 프로젝트의 일환 으로 작년 홍수 수해를 입은 농민들을 대상으 로 비엔티엔시를 비롯하여 17 개지역에 지원 되며 1994년 이후 일본은 118,000 톤(3,776백 만엔)의 식량을 원조했다.

- 일본 민간기업 국립재활센터에 휠체어 지원 - 일본 민간기업인 니치카카우회사(At-home nursing company)가 국제 NGO인 Asian Development with disabled People(ADDP) 요청으로 20 만불 상당의 200 개 휠체어를 국 립재활센터에 기증했다. 이는 노약자, 장애인 들의 재활 및 독립적인 사회활동을 지원하기 위한 것으로 각 지역으로 보내져 장애인들에 게 직접 배포될 예정이다.

- 민중 보호 프로젝트

- 일본은 민중 보호프로젝트로 49 천불상당의 의수족을 지원했고 동 지원은 국립재활센터 를 통해 전쟁상해, 소아마비, 교통사고로 인 한 장애자들에게 지원될 예정이다. 또한, 루 앙프라방에 86,100 불을 지원하여 4700 명 각 성제 중독자를 위한 재활센터를 내년 완공을 목표로 사업을 추진할 계획이다. 재활은 3 개
월 과정으로 1 회에 50 명 중독자를 대상으로 재활교육이 가능할 것이며 동시에 농업 등의 직업 재활교육도 실시할 예정이다. 루앙프라 방에는 6,200 명의 마약 중독자가 있고 해마 다 HIV감염자가 증가하는 추세이다. 2001년 라오 정부는 135 명의 마약소지, 인신매매등 마약사범을 사형시킨 바 있으며 2006년에는 146 명으로 늘어났다. 라오스 정부의 마약근 절 노력은 아세안과 중국과 협약을 맺어 2015년까지 완전 퇴치를 목표로 하고 있다.

- 일본 세계은행을 통하여 라오스 지원

- 일본은 세계은행을 통하여 28.4백만불을 4 개 빈곤퇴치 프로젝트에 지원할 계획이다. 동 지 원은 현재 진행하고 있는 남튼 II(수력발전소 건립)프로젝트와 지속적인 경제발전을 위하 여 씨여질 계획으로 이중 15 백만불은 캄보디 아 전기수출을 위한 사라완지역에 전기공급 송전탑 설치에 투입되고, 3 백만불은 정부 예 산집행, 감사, 보고 개선에 쓰여질 것이다. 기 타 10 백만불은 정부의 예산집행관련 능력함 양을 위하여 집행되어질 것이며 46.9천불은 빈곤퇴치를 위한 교통시설 개선에 사용되어 질 것이다.

\section{II. 스웨덴의 대라오스 지원}

- 스웨덴은 기존 지원국을 70 개에서 33 개국으 
로 축소하기로 하였으며 대 라오스 원조도 단 계적으로 지원을 축소해 나갈 방침이다.

- 스웨덴 정부는 ODA 지원 범주를 빈곤퇴치, 효과적인 원조, 수원국의 인권보호를 통한 민 주화 및 선정 지원, 기타 스웨덴의 비교우위가 있는 분야를 지원하기로 결정했다.

- 스웨덴은 지난 30년간 라오스 원조를 실시하 여 왔으나 라오스 빈곤의 주요 원인이 정치와 인권 보호 수준이 낮은데 기인한다고 판단함 에 따라 향후 2-4년간 단계적으로 지원을 축 소할 계획이다.

- 2008년까지 스웨덴의 대라오스 지원 주요 분 야로는 라오스 재정부 연수실시, 국가 통계청 지원, 교육분야 지원, 라오 국립대 지원이 있 다.

\section{III. 중국의 대라오스 지원}

- 중국정부는 최근 경제발전에 힘입어 점차적으 로 $\mathrm{ODA}$ 를 증대시키고 있으며 양자 채널을 통 하여 무조건으로 공적 지원을 실시해왔다. 지 원 분야로는 기자재 지원, 인적자원 개발, 기 술지원, 무이자 차관, 저이자 차관 등이 있다.

- 대 라오스 지원은 국가 사회경제개발 계획에
부합하는 주재국 자립 능력 개발 지원 분야와 투자 무역협력에 중점을 두어 왔다.

- 중국은 그간 문화, 보건, 인적자원개발 뿐만 아니라 국립문화홀 건립, 파뚝사이 공원건립, 루앙프라방 주립병원 건립, 남고 수력발전소 건립, 방비엥 시멘트 공장 건립 등을 지원하여 왔으며 무상으로 60 만불을 마약재활센터에 지원하기도 했다.

- 중국의 대라오스 지원의 경우, 무상원조와 경 제투자의 경계가 모호한 실정이다.

\section{IV. 프랑스 생활용수 공급을 위한 훈련센터 지원}

- 프랑스는 2.7백만 유로를 투입하여 생활용수 공급을 위한 훈련센터를 건립한다. 동 프로젝 트는 라오스 정부가 프랑스 정부와 공동으로 추진하고 있는 수자원개발관리 및 안전한 식 수보급 프로젝트의 일환으로 라오스 전역의 생활용수를 담당하는 공무원들을 대상으로 교 육을 시킬 계획이며 현재 20 명의 강사가 배정 되어 있다. 


\section{$\mathrm{V}$. 미국 보건부 산하 미타팝병원 지원}

- 미국에 본부를 두고 있는 REI(US-based Resource Exchange International)는 보건 부 산하 미타팝에 인적자원 개발을 지원키로 합의했다. 동 프로그램에는 소아과 종사자 능 력개발 및 의학관련 영어교육, 소아환자 다루 는 법 등이 포함되어 있으며 의료관계자들을 미국 현지로 보내어 연수를 시킬 계획이다.

\section{EU 북쪽지역에 35 개학교 지원}

- 유럽연합은 북쪽지역 퐁살리, 루앙프라방, 루 앙남타 3 개주에 35 개의 초등학교 건립하여 기 초 교육을 지원키로 했다. 동 프로젝트는 북쪽 지역에 기초 교육개발 프로젝트의 일환으로 100 개 초등학교 건립사업의 일부이다. 동 프 로젝트의 예산은 라오정부가 40만유로, 유럽 연합이 6백만 유로를 부담하여 2004-2010년 까지 추진될 예정이다.

- 동 초등학교는 상기 3 개주(퐁살리주, 루앙프 라방주, 루앙남타주) 9개군(남타군, 비엥포카 군, 롱군, 촘펫군, 비엥캄군, 크후아군, 삼판 군, 마이군, 옷투군)에 건립될 예정이다. 동 군 의 취학율 및 교육환경은 열악한 수준이고 교 실 역시 부족한 실정이라서 2007-2008년까
지 95 개 교실을 더 확장할 계획이다. 소수종 족 430 개 마을 6,000 명의 어린이가 수혜 대 상이고 교사 1,200 명의 훈련도 포함된다. 또 한 성인 10,000 명을 대상으로 한 비정규 교육 과정 지원도 포함된다.

- 마을단위로 각 35 만유로를 지원하여 주민들 이 설계에서 시공까지 참여하여 보다 적극적 인 협력체계 유도와 동 사업에 대한 관심을 제 고할 예정이다.

\section{VII. 독일 우돔사이주 학교 중퇴자 지원}

- 경제적인 문제로 학교교육을 받지 못하는 우 돔사이주 500 명 학교 중퇴자를 위해 독일 GTZ에서 1.5 백만불 예산으로 직업훈련원을 건립할 계획이다. 기존에 있는 직업훈련학교 의 교육환경은 열악할 뿐만 아니라 1200 명 학 교 중퇴자 중 60 명만이 가축사육, 농업, 기술 등 취업을 위한 교육을 받고 있었다. 새로 건 립될 직업훈련 학교의 규모는 10 개동에 각 교 실 6-7개규모로 한 교실에 40명을 수용할 수 있다. 그동안 독일은 라오스에 지속적으로 직 업훈련분야를 지원하여 왔다. 


\section{UN Habitat 루앙프라방에 급 수시설 지원}

- UN Habitat는 루앙프라방주 씨엥눈, 빡칸, 팍배드, 팍또마을에 식생활수 공급할 수 있는 파이프라인 설치하여 6,400 여명이 농업용수, 가축사육, 생활용수로 사용하는 등 수혜를 얻 었다. 급수시설은 용천수를 활용 중력으로이 용하였으며 예산은 UN Habitat 25만불, 해당
군에서 10 만불, 식수공급 기관에서 15 만불이 투입되었다. 물공급은 국가경제와 빈곤퇴치를 위한 4대 우선과제 중 하나이다. 주재국내 급 수시설 지원은 $\mathrm{ADB}$ 에서 총 300 백만불을 투 입하고 있고(50만불-능력함양, 250만불- 남 중부지역 물공급 시설 지원) 캐나다 등이 모니 터링 및 사업 수행에 참여하고 있다.

[자료: 주라오스대사관] 